\title{
Morphological Particularities of Population of Rumen Protozoa in Domestic Ruminants
}

\author{
Laura Cristina ŞTEFĂNUȚ ${ }^{1)}$, Laurențiu OGNEAN, ${ }^{23^{*}}$, Şerban, NICULESCU, ${ }^{3)}$ Pompei BOLFĂ ${ }^{4}$ \\ 1,2,3, Department of Animal Physiology. University of Agricultural Sciences and Veterinary Medicine of \\ Cluj-Napoca, Romania \\ 4. Department of Pathological Anatomy. University of Agricultural Sciences and Veterinary Medicine of \\ Cluj-Napoca, Romania. \\ Corresponding author: lognean@yahoo.com
}

Bulletin UASVM Veterinary Medicine 72(1) / 2015,

Print ISSN 1843-5270; Electronic ISSN 1843-5378

DOI:10.15835/buasvmcn-vm: 10633

\begin{abstract}
Introduction: Rumen is a complex ecosystem in which food consumed by ruminants is digested by symbiotic microorganisms. Fermentations result at this level is volatile fatty acids and microbial biomass, which are used by the host as a nutrient substrate. Between ruminal microorganisms (bacteria, protozoa and fungi) and host are diverse interactions (adaptability and symbiosis) which provides advantages in the ability of ruminant digestion.

Aims: The main objectives of this study were: development of new methods of fixing, staining and identification of rumen protozoa; morpho-physiological characterization of rumen protozoa subfamilies and genera; investigations of the structure of rumen protozoa populations in domestic ruminants.

Materials and methods: Sampling of investigated animals ( 5 cattle, 5 sheep, and 5 goats) was collected by of ruminal survey method. Rumen fluid was preserved in formalin (9.5\%) and MFS (Methyl green-formalin-sodium chlorate). Examination of samples was achieved by performing the native method and stained preparations and then exposed under a microscope (optical and confocal). Criteria for identification of protozoa were: number and location of ciliary areas; cell shape and size; location, number and size of skeletal plates; presence of caudal spines.

Results: Rumen protozoa counting results revealed different mean values for the three ruminant species, the highest levels were recorded in goats $\left(7.39 \times 10^{6} / \mathrm{ml}\right.$ rumen fluid $)$, followed by cattle $\left(4,958 \times 10^{6} / \mathrm{ml}\right.$ rumen fluid $)$ and sheep, with much lower averages $\left(1,814 \times 10^{6} / \mathrm{ml}\right.$ rumen fluid).

Conclusion: The analysis of rumen protozoa population in cattle, sheep and goats revealed predominance of the following genres: Isotricha, Dasytricha, Entodinium, Epidinium, Ophryoscolex and some types of subfamily Diplodiniinae (Diplodinium, Eudiplodinium, Poliplastron).
\end{abstract}

Keywords: cuantification, identification, rumen protozoa, ruminants

\section{INTRODUCTION}

The rumen is a complex ecosystem in which the food consumed by ruminants is digested by various microorganisms very active. The results of fermentations at this level are the volatile fatty acids and microbial biomass, which are used by the host as a nutrient substrate.

Between ruminal microorganisms (bacteria, protozoa and fungi) and host is performed various interactions (adaptability and symbiosis) which provides an advantage in digestion and the ability to use feed rich in fibers and low in protein (Weimer, 1996; Hackstein, 2010).
Modern animal nutrition practices are oriented to intensification of the milk and meat production, and presents a new challenge for ruminal microorganisms.

Proposals for manipulation of ruminal microorganisms were, generally, limited and rarely was considered the great complexity ruminal microbial ecology (Weimer, 1996; Prins and Stewart, 1994).

The main objectives of our study were: morpho-physiological characterization of subfamilies and genera of rumen protozoa; investigation 
of the structure of rumen protozoa populations prevalent in domestic ruminants

\section{MATERIALS AND METHODS}

The research study was conducted between November 2012 and March 2013 in the Faculty of Veterinary Medicine Cluj-Napoca in animal physiology laboratory, medical clinic and small ruminants hospital. For the study we used three groups of animals with 5 cows, 5 sheep and 5 goats. The animals were maintained in the hospital of veterinary medicine faculty. Throughout the study period the animals were fed with concentrates and good quality hay

Collection of biological samples - ruminal juice was collected individually with ruminal probe. From each animal were collected, 5 samples of ruminal juice. Rumen protozoa are sensitive to thermal shock (Peterson, 1999), for this the samples of ruminal fluid were collected and transported using the thermally insulated container.

The fixing of the rumenal juice samples was preserved in formalin (9.5\%) and MFS (Methyl green-formalin-sodium chlorate). Examination of samples was achieved by performing the native method and stained preparations and then exposed under a microscope (optical and confocal). Quantification of rumen protozoa was made by cytometric methods by using Fuchs Rosenthal counting chamber.

Examination of ruminal samples - for examination of the samples we used optical microscope Olympus BX 51; were used 10x, 20x and 40x and 100x magnification and phase contrast microscopy and images were taken with Olympus SP 350 digital camera and processed with Olympus Cell software. It has also been used a Zeiss LSM 710 confocal laser with microscope Zeiss inverted AXIO Observer Z1.; combination, processing and analysis of images was performed by analysis program ZEN. We have used two fluorescence channels: CH1: 547-629 nm $(543 \mathrm{~nm}$ HeNe laser) and CH2: $667-757 \mathrm{~nm}(633 \mathrm{~nm} \mathrm{HeNe}$ laser). Confocal images were performed with Plan Apochromat $63 \mathrm{x}$ objective (oil immersion) of Zeiss.

Identification of rumen protozoa - for the identification of protozoa was used the method of fixing / staining / storage MFS. MFS (Methyl Greenformalin-sodium chlorate) is a good preservative and colorant, it has the ability to stain the nucleus of the cell (shape and position of the nucleus is one of the criteria used in the classification of the rumen protozoa). Identification of rumen protozoa can be made at the level of subfamily/ genus or species. (Makkar and McSweeney, 2005). For each gender were identified between 10 and 50 protozoa specimens.

Tab. 1. Rumen protozoa identification keys (Makkar and McSweeney, 2005)

\begin{tabular}{|c|c|c|}
\hline No. & criteria for identifying & subfamily / genus \\
\hline 1. & cilia all over the body & 4,5 \\
\hline 2. & cilia at the anterior end of the body - the oral zone & 6 \\
\hline 3. & $\begin{array}{l}\text { cilia at the anterior end of the body plus a secondary } \\
\text { area with cilia located in a different area. }\end{array}$ & 7 \\
\hline 4. & $\begin{array}{l}\text { cilia disposed in longitudinal rows parallel to the long } \\
\text { axis of the body; body size over } 100 \mu \mathrm{m} \text { in length. }\end{array}$ & genus Isotricha \\
\hline 5. & $\begin{array}{l}\text { cilia disposed in longitudinal rows like a spiral around the long } \\
\text { axis of the body; body size over } 50-75 \mu \mathrm{m} \text { in length. }\end{array}$ & genus Dasytricha \\
\hline 6. & $\begin{array}{l}\text { the cilia are around the oral cavity at the anterior end of the body; } \\
\text { only one contractile vacuole, macronucleus is near to the dorsal wall } \\
\text { of the body; micronucleus is on the ventral side of macronucleus }\end{array}$ & genus Entodinium \\
\hline 7. & $\begin{array}{l}\text { a secondary area with cilia in the transverse plane identical with the cilia of } \\
\text { the anterior end of the body; operculum present; two or more contractile } \\
\text { vacuoles; body size between } 50-350 \mu \mathrm{m} \text {; micronucleus located between } \\
\text { macronucleus and dorsal body wall; skeletal plates may be present }\end{array}$ & subfamily Diplodiniinae \\
\hline 8. & $\begin{array}{c}\text { A dorsal area with cilia in the form of short bands, } \\
\text { located at the posterior of the cell. }\end{array}$ & genus Epidinium \\
\hline 9. & $\begin{array}{l}\text { the dorsal area with cilia is a band that surrounds three to four } \\
\text { times the body until one third of the posterior end of the cell }\end{array}$ & genus Ophryoscolex \\
\hline
\end{tabular}


In general, are used the following criteria (Makkar and McSweeney, 2005; Dehority, 1993, Williams and Coleman, 1992) in order to classify and identify rumen protozoa (Tab. 1.):

- the presence of cilia on the whole surface of the

cell or in one or more separate areas;

- number and location of ciliary areas;

- overall shape of the cell and its dimensions, including length / width ratio (L/l);

- number and location of the contractile vacuole;

- presence of terminal spines.

Rumen protozoa population structure to determine the structure of rumen protozoa populations have respected the same criteria of identification. For each species of ruminant were identified 100 specimens of protozoa. Appreciation of results were expressed by percentage distribution.

\section{RESULTS AND DISCUSSION}

Quantification of rumen protozoa. From the point of view of the number of rumen protozoa were revealed important differences depending on the species of ruminant (Tab. 2.). We believe that the differences found between the three ruminant species may be due to the specific particularities of the structure of the feed and intensity fermentative processes of the digestion.

Morphological characterization of rumen protozoa with optical microscope. Identification of rumen protozoa from cattle, sheep and goats, revealed the following genres: Isotricha, Dasytricha, Entodinium, Epidinium, Ophryoscolex and subfamily Diplodiniinae with genres Diplodinium, Eudiplodinium, Poliplastron.

Identification and differentiation of ciliated protozoa have revealed the various morphological particularities for each genus :

1. Genus Isotricha (Fig.1)- cilia all over the body; length $=122.93 \pm 17.6 \mu \mathrm{m}$; width $=58.23 \pm$ $4,9 \mu \mathrm{m}$; area $=3735.58 \pm 324 \mu \mathrm{m}^{2}$.

2. Genus Dasytricha (Fig.2)- cilia all over the body; length $=74.93 \pm 6.9 \mu \mathrm{m}$; width $=44.73 \pm 9.2 \mu \mathrm{m}$; area $=2728.85 \pm 643.7 \mu \mathrm{m}^{2}$.

3. Genus Entodinium (Fig.3)- one area of cilia around oral cavity; the presence of a tail at the posterior; length $=36.67 \mu \mathrm{m}$; width $=20.56 \mu \mathrm{m}$; area $=515.03 \mu \mathrm{m}^{2}$.

4. Genus Diplodinium (Fig.4)- cilia area at the anterior end of the cell and a secondary zone of cilia (the dorsal cilia) located in transverse
Tab. 2. Quantification of rumen protozoa in the animals investigated $\left(\mathrm{n} \times 10^{6} / \mathrm{ml}\right)$

\begin{tabular}{cccc}
\hline No. & cattle & sheep & goats \\
\hline 1. & 4.78 & 0.98 & 9.28 \\
\hline 2. & 4.89 & 2.72 & 7.13 \\
\hline 3. & 3.12 & 0.75 & 5.12 \\
\hline 4. & 6.78 & 3.98 & 6.45 \\
\hline 5. & 5.32 & 0.64 & 8.97 \\
\hline AVERAGE & $\mathbf{4 . 9 5 8}$ & $\mathbf{1 . 8 1 4}$ & $\mathbf{7 . 3 9 0}$ \\
\hline ST. $\boldsymbol{D E V}$. & $\mathbf{1 . 3 1 0}$ & $\mathbf{1 . 6 0 1}$ & $\mathbf{1 . 7 4 4}$ \\
\hline
\end{tabular}

plane; operculum in the oral extremity of the cell; length $=52.05 \pm 4.32 \mu \mathrm{m}$; width $=47.93 \pm$ $2.89 \mu \mathrm{m}$; area $=987 \pm 93 \mu \mathrm{m}^{2}$.

5. Genus Eudiplodinium (Fig.5) - cilia area at the anterior end of the cell and a secondary zone of cilia (the dorsal cilia); small skeletal plate with inconstant presence; length $=65.37 \pm 11.9 \mu \mathrm{m}$; width $=40.85 \pm 8.27 \mu \mathrm{m}$; area $=1833.8 \pm 79$ $\mu \mathrm{m}^{2}$.

6. Genus Poliplastron (Fig.6 - cilia area at the anterior end of the cell and a secondary zone of cilia (the dorsal cilia); 5 narrow skeletal plates; large operculum; length $=102.87 \pm 11,90 \mu \mathrm{m}$; width $=61.09 \pm 1.20 \mu \mathrm{m}$; area $=3978.35 \pm 320$ $\mu \mathrm{m}^{2}$.

7. Genus Epidinium (Fig.7) - cilia area at the anterior end of the cell and a secondary zone of cilia (the dorsal cilia) as a short band located in the center or in the posterior of the cell; inconstant presence of skeletal plates; length $=$ $65.37 \pm 2.73 \mu \mathrm{m}$; width $=40.85 \pm 5.87 \mu \mathrm{m}$; area $=1833.8 \pm 134 \mu \mathrm{m}^{2}$.

8. Genus Ophryoscolex (Fig.8) - cilia area at the anterior end of the cell and a secondary zone of cilia (the dorsal cilia) as a helicoidal bandcaudal spines to the posterior part of the cell; presence of skeletal plates; length $=123.74 \pm 0,46 \mu \mathrm{m}$; width $=78.35 \pm 11,2 \mu \mathrm{m}$; area $=7695.02 \pm 341$ $\mu \mathrm{m}^{2}$.

Morphological characterization of rumen protozoa with confocal microscope.

By examining with the confocal microscope has revealed autofluorescence of the rumen protozoa. This technique reveals very well the shape, size and position of the nucleus in the cell; were observed contractile vacuoles and protozoa cilia.

By this method of investigation we observed the following aspects: 


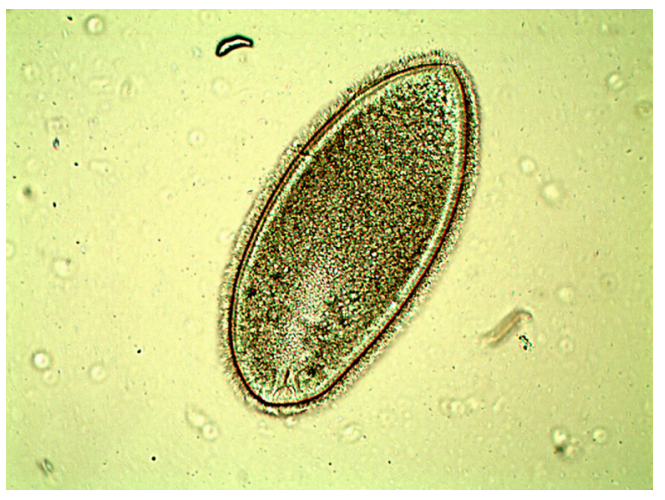

Fig. 1. Genus Isotricha (40x, MFS).

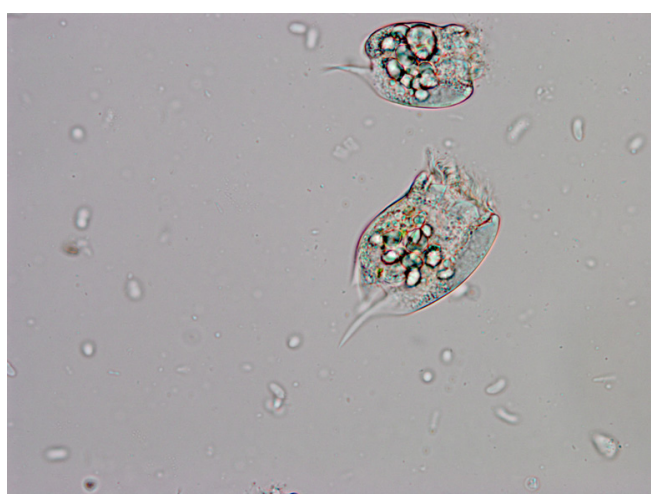

Fig. 3. Genus Entodinium (40x, MFS).

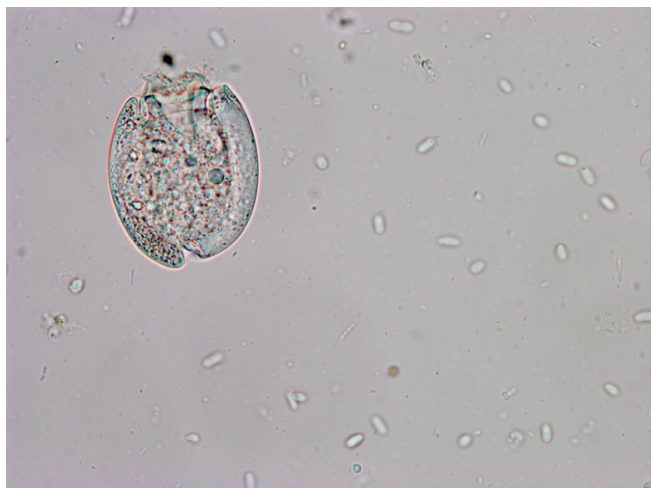

Fig. 5. Subfamily Diplodiniinae, genus Eudiplodinium (40x, MFS).

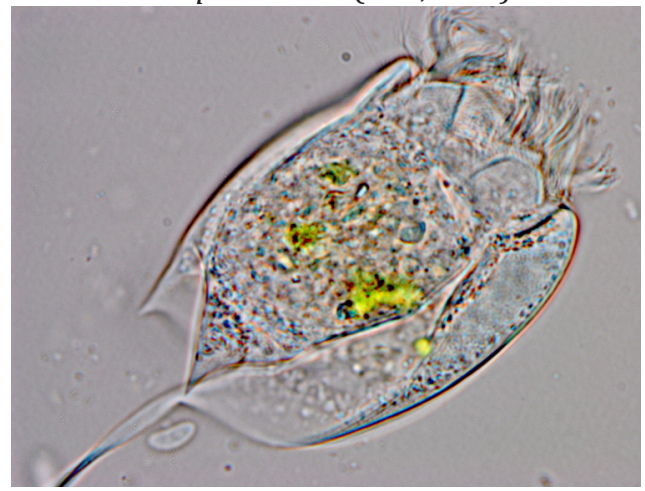

Fig. 7. Genus Epidinium (100x, MFS).

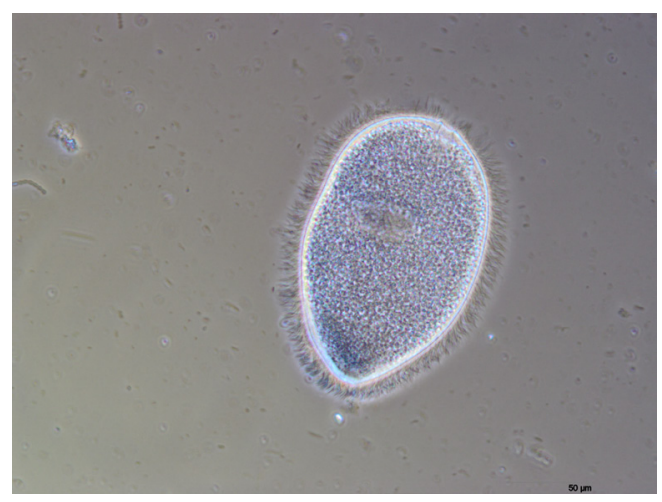

Fig. 2. Genus Dasytricha (40x, MFS)

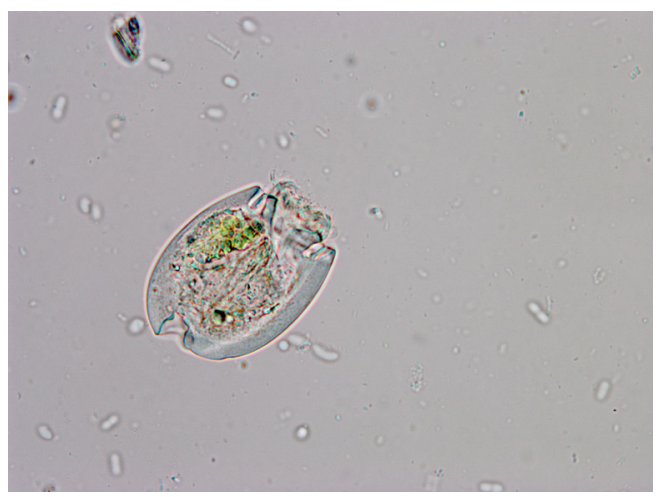

Fig. 4. Subfamily Diplodiniinae, genus Diplodinium (40x, MFS).

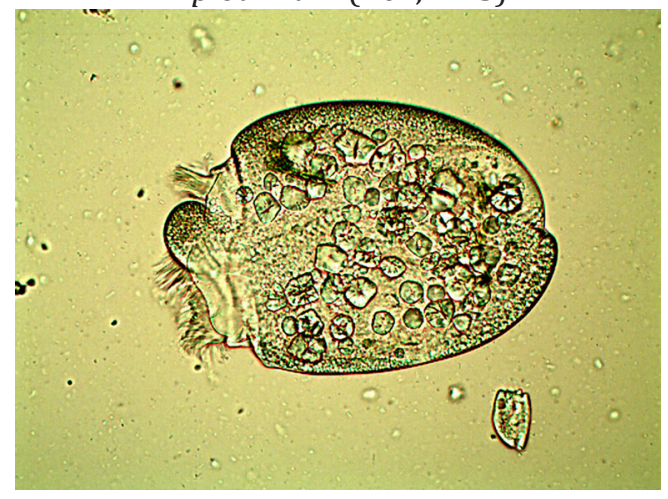

Fig. 6. Subfamily Diplodiniinae. Genus Poliplastron (40x, MFS).

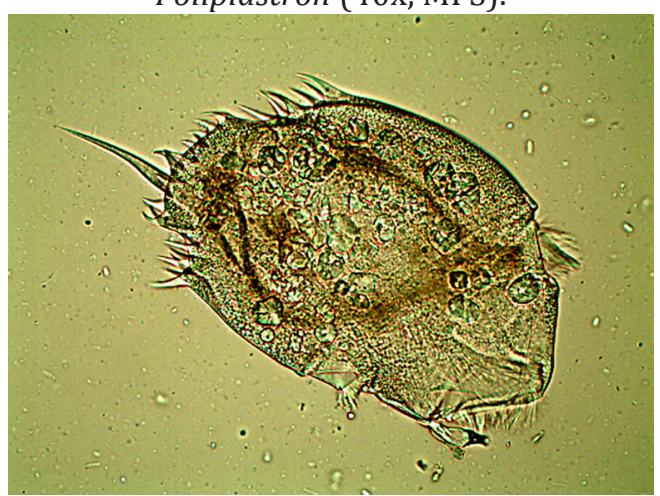

Fig. 8. Genus Ophryoscolex (40x, MFS). 


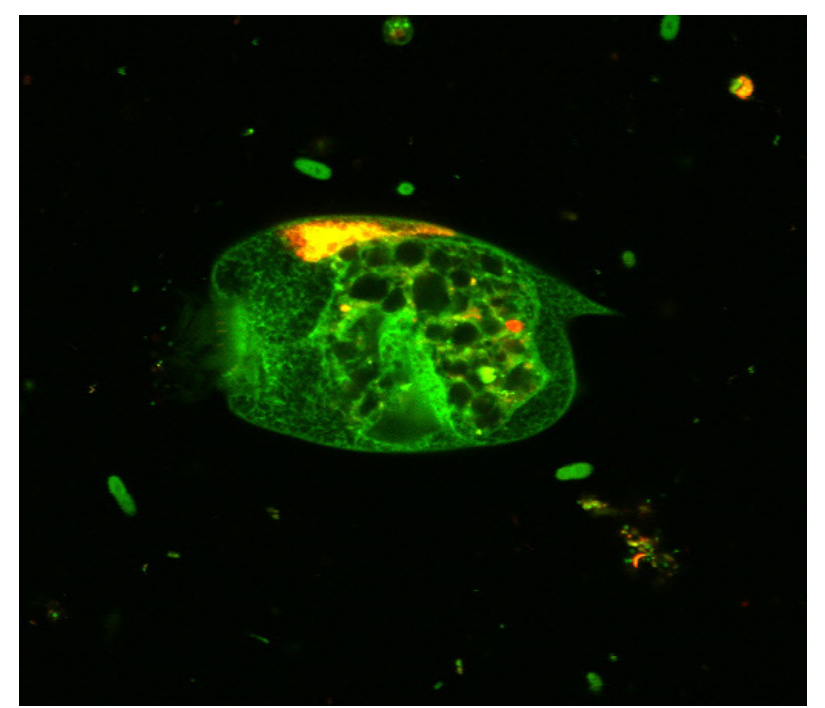

Fig. 9. Genus Entodinium (63x)

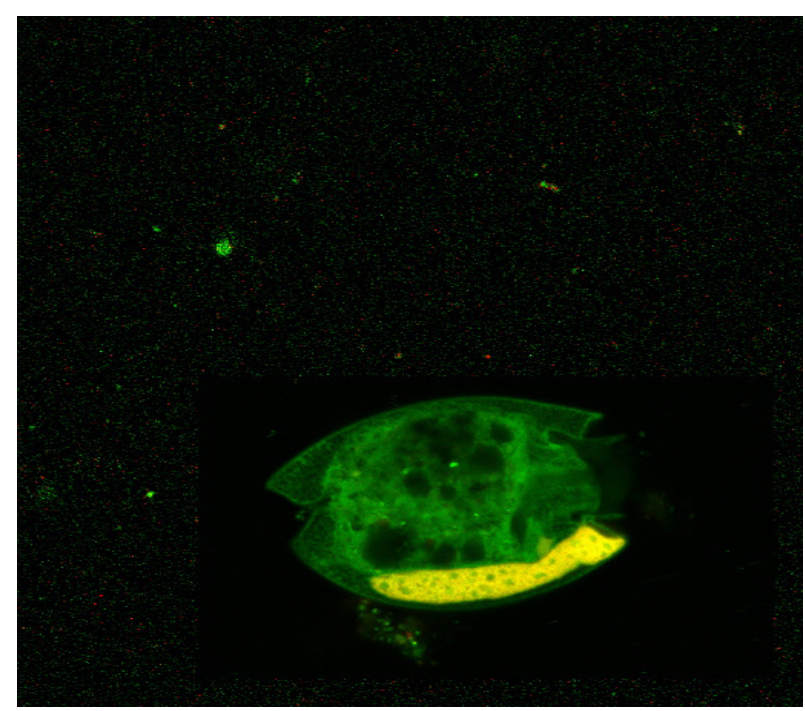

Fig. 11. Subfamily Dipolodiniinae (63x)

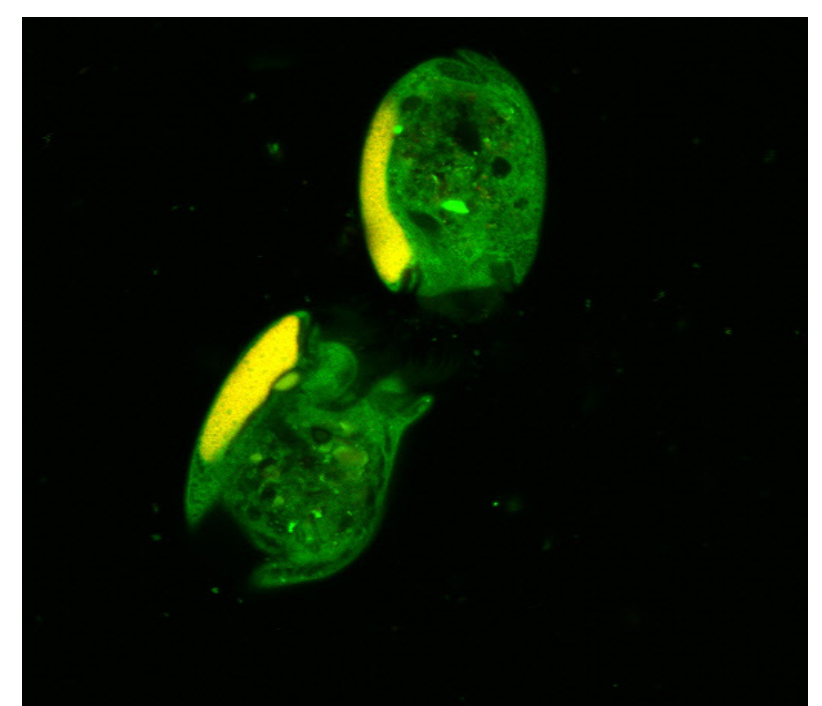

Fig. 10. Subfamily Diplodiniinae (63x)

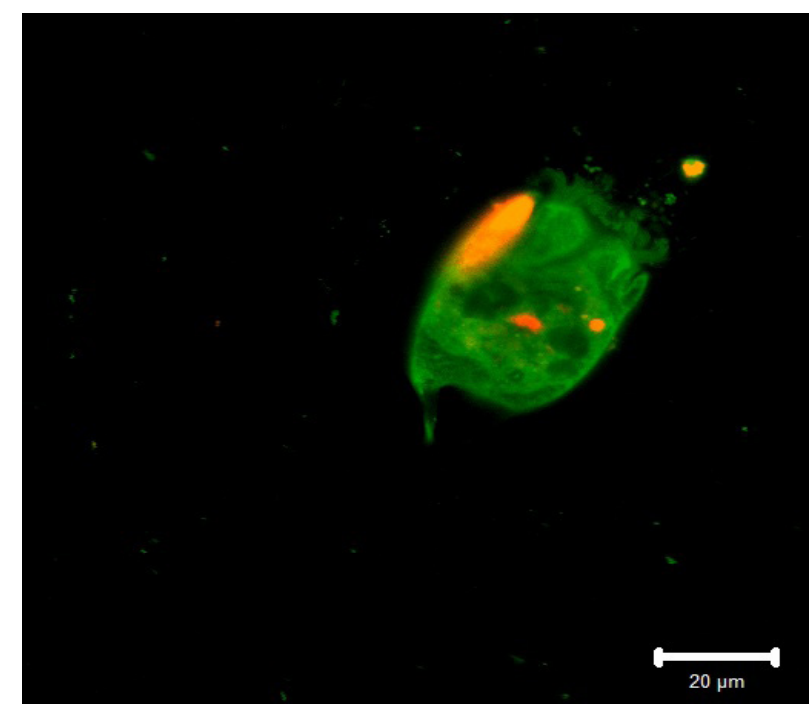

Fig. 12. Genus Epidinium (63x)

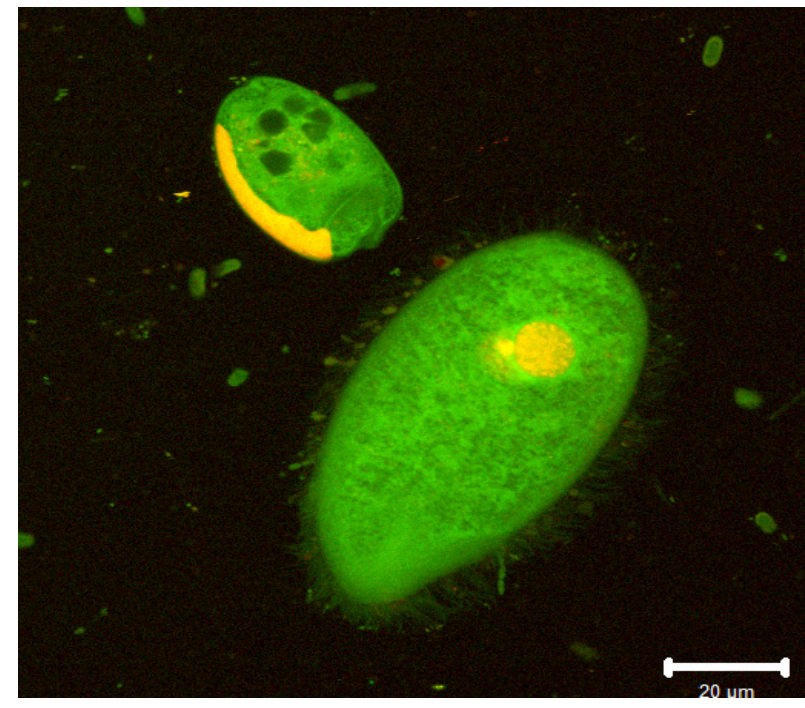

Fig. 13. Genus Isotricha (63x) 
1. Genus Entodinium (Fig. 9)- macronucleus was positioned in the posterior part of the cell, pointed to the posterior part and represent approximately one third of the length of the cell. The shape of the cell was oval and we observed the presence of the posterior tail.

2. Subfamily Diplodiniinae (Fig. 10, 11)elongated cell and caudal region was identified cytoproct; cilia were arranged in two distinct areas. Macronucleus slightly curved, was located in the dorsal region of the cell and occupies almost the entire length of the cell. Micronucleus was located ventral to macronucleu having oval shape. In the cell cytoplasm were found contractile vacuole.

3. Genul Epidinium (Fig. 12)- elongated cells, in the caudal part of the cell was observed the tail. The cilia were arranged in two distinct areas: the oral cilia and the dorsal cilia. Macronucleus was in the dorsal part of the cell, has oval-elongated shape and occupy about half of the length of the cell. In the cytoplasm were identified contractile vacuole.

4. Genus Isotricha (Fig.13)- macronucleus has discoidal shape and is located in the anterior third of the cell; micronucleus was located near macronucleus; was observed the oval shape of the cell and cilia disposed all over the body.

Rumen protozoa population structure. The population of the rumen protozoa may vary depending on many factors which act on the animal (Falcă et al., 2011).
The rumen protozoa population was different depending on the animal species from which was collected the ruminal contents. The season in which was collected the samples and the type of feeding influenced protozoa population, so the population structure was different in animals that were fed with green fodder to those fed fibrous forage. A very important factor that influenced the structure of rumen protozoa population was hydric regime and season. Population structure was different compared anteprandial and postprandial structure (Ognean et al., 2004; Ognean and Cernea, 2011).

In the case of cattle the rumen protozoa population structure was dominated by the genus Entodinium (28\%) and Diplodinium (26\%). The samples examined were highlighted for protozoa of the genus Eudiplodinium (Fig. 14).

In the ruminal juice samples collected from sheep, were not observed the presence of protozoa of the genera Dasytricha and Ophryoscolex; the population structure was dominated by genera Entodinium (35\%) and Epidinium (43\%) (Fig. 15).

At goats were found all 8 genera of protozoa identified by us, the higher level was for Epidinium (33\%) and Entodinium (28\%) (Fig. 16).

Regardlessoftheruminantspeciesinvestigated, were observed absence or presence of very small level for ciliated protozoa of the genera Dasytricha and Eudiplodinium; medium level was evidenced for genus Isotricha, Ophryoscolex and Poliplastron. In general, was evidenced the dominance of genus

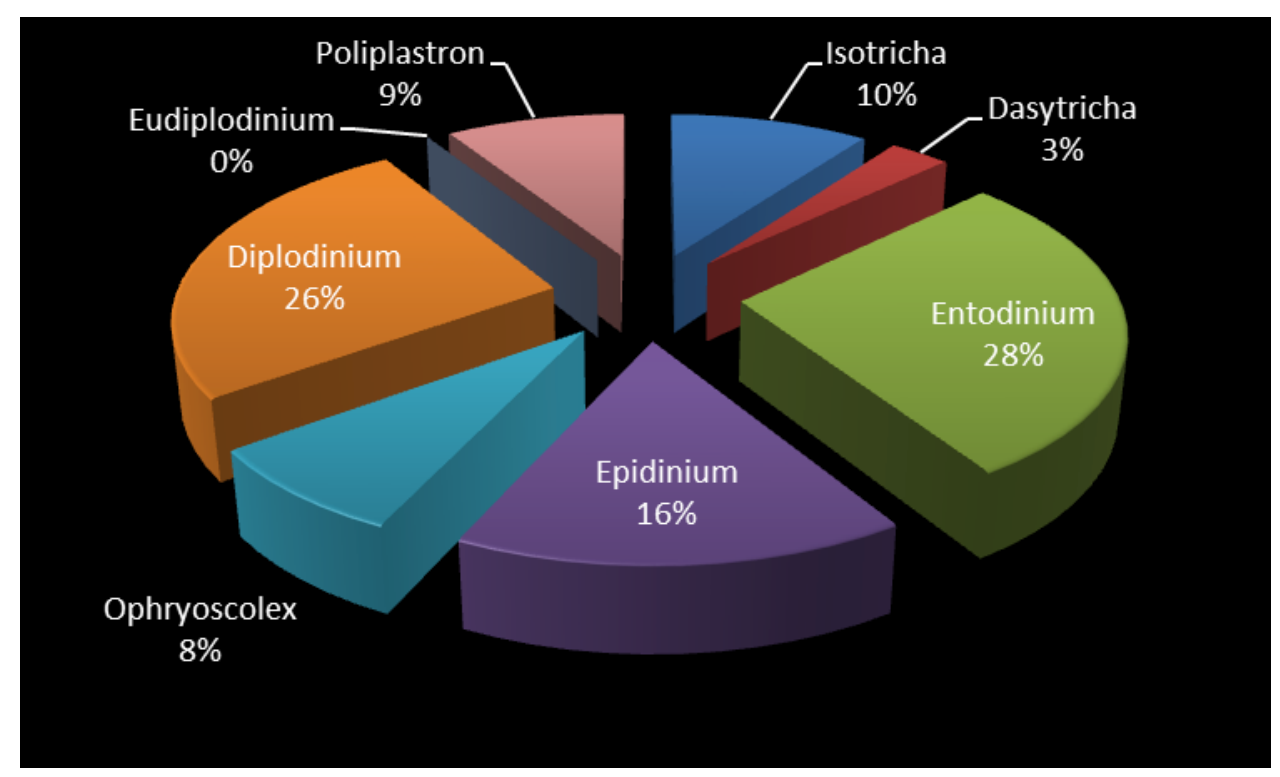

Fig. 14. The percentage distribution of ruminal protozoa in cattle 


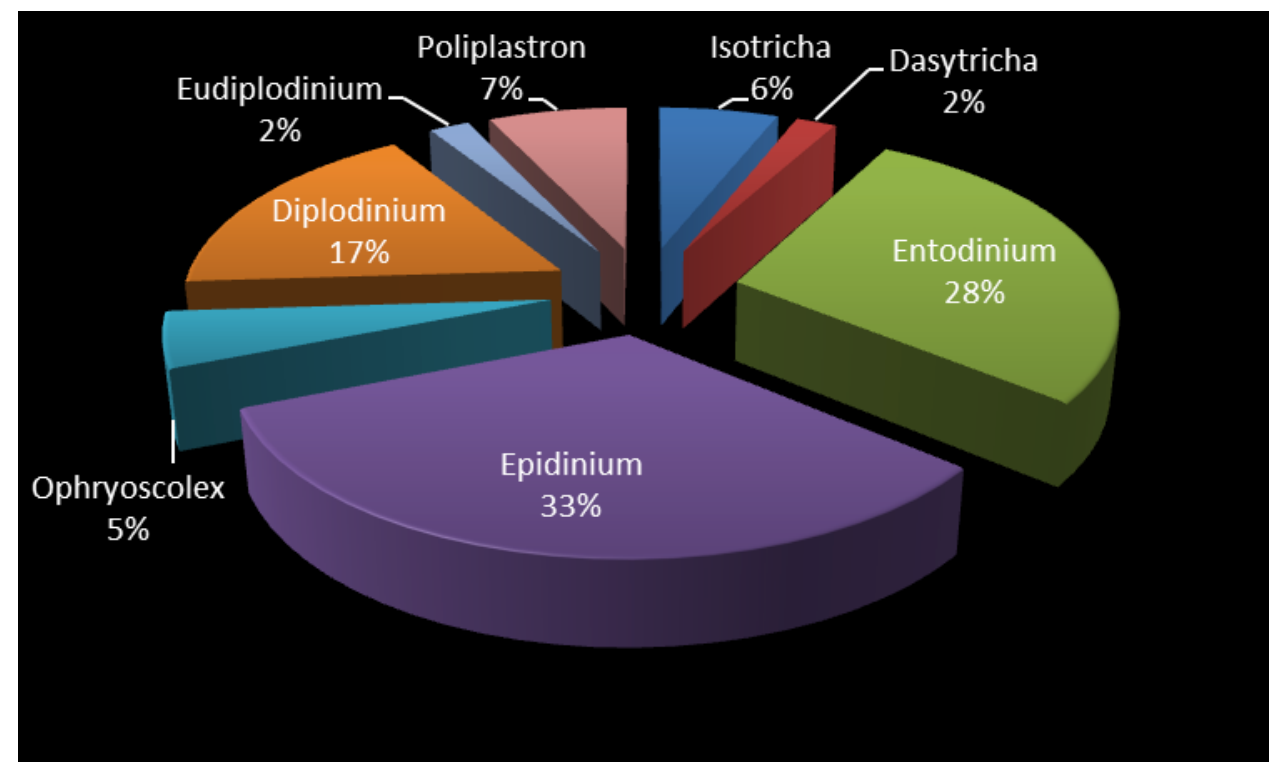

Fig. 16. The percentage distribution of ruminal protozoa in goats

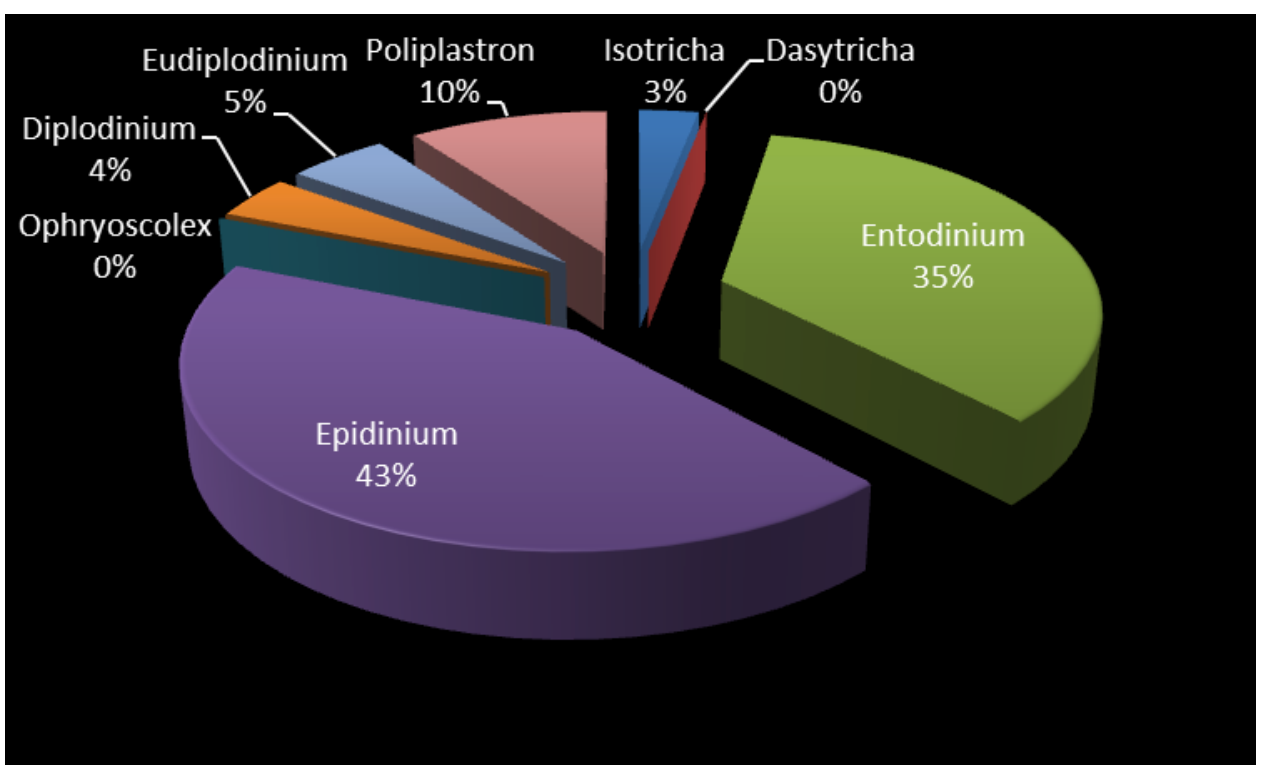

Fig. 15. The percentage distribution of ruminal protozoa in sheep

Entodinium, Epidinium and Diplodinium . Factors which affect the structure of the protozoa can be method of collection of ruminal juice and the region where ruminal contents was collected. To see all content distribution of protozoa in ruminal juice we indicate the collection of biological samples permanent ruminal fistula; in this way we can collect the ruminal juice from different rumen regions.

\section{CONCLUSIONS}

Different mean values of ciliate protozoa were found in the three species of ruminants, the highest levels were recorded in goats $\left(7.39 \times 10^{6} /\right.$ $\mathrm{ml}$ rumen juice), followed by cattle $\left(4,958 \times 10^{6} /\right.$ $\mathrm{ml}$ rumen juice) and sheep with lower averages $\left(1,814 \times 10^{6} / \mathrm{ml}\right.$ rumen juice $)$.

The analysis of rumen protozoa population identified in cattle, sheep and goats revealed the predominance of the following genres: Isotricha, Dasytricha, Entodinium, Epidinium, Ophryoscolex and of subfamily Diplodiniinae (Diplodinium, Eudiplodinium, Poliplastron).

Microscopic examination with the confocal system revealed the autofluorescence of the ruminal protozoa which facilitated the observation 
of shape, size and position in the of the nucleus in the cell.

\section{REFERENCES}

1. Dehority B A (1993). Laboratory manual for classification and morphology of rumen ciliate protozoa. Nottingham University, Nottingham, 15-30, 45-68, 80-103.

2. Falcă C-tin, Mircean M, Moț T, Brăslaşu C M, Giurgiu G, Vlăgoiu C, Pop C, Papuc I, Solcan G, Vulpe V (2011). Medicina internă a animalelor vol. I. Eurostampa, Timişoara, 67-88.

3. Hackstein Johannes (2010). (Endo)symbiotic methanogenic archaea. Springer, London, 25-35.

4. Makkar H, McSweeney C S (2005). Methods in gut microbial ecology for ruminants. Springer, Dordrecht, 6780.
5. Ognean L, Cernea Laura Cristina (2011). Aplicații practice în fiziologia animalelor. AcademicPres, Cluj-Napoca, 184187.

6. Ognean L, Dojană N, Roşioru Corina (2004). Fiziologia animalelor vol. I. Presa universitară clujeană, Cluj-Napoca, 102-118.

7. Peterson D (1999). Rumen ciliates. Alaska Science Consortium, Great Northem Science Handbook, 1-13.

8. Prins AR, Stewart CS (1994). Micro-organism in ruminant nutrition. Nottingham University, Nottingham, 125-153, 174-198.

9. Weimer P (1996). Ruminal cellulolytic bacteria. Academic Press, New York, 18.

10. Williams AG, Coleman GS (1992). The rumen protozoa. Springer, London, 23-50, 81-89, 112-170, 225-280. 